\title{
Fake News as a Tool to Manipulate the Public With False Information
}

\author{
Munadhil Abdul Muqsith ${ }^{1,}{ }^{*}$ Rizky Ridho Pratomo ${ }^{2}$ Anna Gustina Zaina ${ }^{3}$ Ana
}

Kuswanti $^{4}$

\author{
1, RUDN University, Moscow, Russia \\ 2, ENERGI Bogor Indonesia \\ 3, Communication Department, Universitas Lampung \\ 4, Universitas Pembangunan Nasional Veteran, Jakarta \\ *Corresponding author. Email: munadhil@upnvj.ac.id
}

\begin{abstract}
This article explains that fake news is not a new phenomenon and is used by various parties throughout civilization. Fake news has become the subject of public discussion lately. The issue of fake news arose because of the support of technology, especially the internet. The internet has accelerated the spread of fake news to a different level. Donald Trump's victory became a symbol of the start of an era called post-truth where truth is secondary. Subjective emotion is the number one benchmark in judging whether a news story is true or not. However, what needs underlining is that the phenomenon of fake news is not new. They have existed since royal times and use for various purposes. However, when it comes to impact and the tools used, there are indeed many differences. Therefore, the author wants to describe the development of fake news further to get a clear picture of the evolution and application of fake news. The conclusion is that there is a significant influence of technological developments. In addition, the purpose of spreading fake news has not changed, which is that it uses to manipulate the public by spreading false information.
\end{abstract}

Keywords: Fake news, False information, Post-truth, Technology

\section{INTRODUCTION}

The phenomenon of fake news or fabricated information has become a serious challenging in the internet era. Its diffusion reflects a situation in which objective facts are less influential in shaping public opinion than attracting personal emotions and beliefs. The speed of information has increased drastically, with messages now spreading anonymously within seconds. The flood of information overwhelms the reader, indicating the validity of the information. Technological growth is not worth fighting the spread of fake news Because the spread is faster and easier since the era of the internet and smartphones. Before there was the internet, people accessed information from print media, radio, or television [1].

Because there are fewer sources providing news, an easy and accurate medium is also possible, but with internet news moving online, suddenly anyone can post information on places like Facebook and Twitter with so much information coming from all angles, easily gullible, especially when an article is made to look like a verified news source, people generally believe it's true because it looks like this news is happening more than ever; in fact, IPSOS Public Affairs study in 2016 showed that $75 \%$ of American adults seeing fake news thought it was real [2]. It becomes the fact that it is difficult to distinguish between genuine and false information. Even our own eyes can be deceived. This is called deep fake news.

The author took the example of fake news viral that shocked the international community in the early March of the Covid-19 pandemic. A photo of a lion at a crossroads at night came out with the caption headline: "President Putin released 800 tigers and lions to force residents to stay at home". This news spread to my country Indonesia, which was in Moscow, and asked by an Indonesian friend the truth of this information. During the pandemic and lockdown at that time, no lions were released on the streets to frighten the 
residents. After the author checked, the article came from the daily.co.uk page, which was uploaded on April 15, 2016, not new news. The real title is "Paws at the traffic lights! A giant male lion is seen prowling around the streets of South Africa's biggest city" (but it's not as dangerous as you'd think). The content of the article reports a lion named Columbus roaming the city of Johannesburg, South Africa, not Russia, and aims to shoot a film. The lion also came from a zoo in South Africa. Once in the spread of fake news, it crosses national borders [3]. Sometimes such satirical images are used by certain parties for comedy, clickbait, and even propaganda. That is why we need to know more about what fake news is, what the typology is and what forms of fake news and its spread.

\section{LITERATURE REVIEW}

Some experts have taken the lead in publishing their views on fake news how many years back. The author divides two expert studies; first, the study after the election of President of America 2016, Donald Trump, who is a lot of experts called the 'post-Truth' era. Of course, this study relates a lot of fake news to sociopolitical conditions. Several scholars' writing includes Brian G. Southwell, Emily A. Thorson, and Laura Sheble [4], showing conceptual differences between misinformation and disinformation and discussing the basis of truth needed to define misinformation. Lazer, et.al. [5] remind us of the importance of process and intention when constructing the concept of "fake news", whereas Jack [6] further outlines the conceptual differences and similarities among a series of concepts related to problematic information, from disinformation to propaganda. Edson C. Tandoc Jr., Zheng Wei Limand and Richard Ling [7], on the other hand, analysed how the term "fake news" was specifically used by scholars and developed a typology based on facts and intent to deceive. They placed different types of online content on these two dimensions, with propaganda, for example, scoring high on both. In contrast, fabrication was low on facticity but high on deceptive intent, and satire being high on factify and low on intent to deceive. Finally, Muqsith and Muzykant [8] said that the effect of fake news has an impact on the destruction of social order and has an impact on the destruction of modern democracy. They cited various elections whose people were polarized, one of the results of fake news from social media, such as in the 2016 US Presidential election, Britain's exit from the European Union which was termed Brexit, the presidential election in Paris, Germany and others [9].

Second, the spread of infodemics during the COVID-19 Pandemic. The misinformation epidemic spread widely and massively on social media after WHO declared the world of coronavirus emergency 2019. Various researchers wrote studies, among others,
John Zarocostas [10] who wrote the theme of how to fight infodemics, Daniele Orso, Nicole Fadrici, Roberto Copetti, Lugi Vertugno \& Triziana Bove [11] who wrote the theme Infodemics and the dissemination of fake news in the COVID-19 era, Rasmus Kleis Nielsen, Richard Fletcher, Nic Newman, J. Scott Brennen, \& Phillip N. Howard [12] wrote Infodemic navigation: how society in six countries accessing and the value of news about coronavirus information, Daniel $H$. Solomon, Richard Bucala, Mariana J. Kaplan, Peter A. Nigrovic [13] wrote the theme Infodemic COVID-19, Aaron Gazendam, Seper Ekhtiari, Erin Wong, Kim Madden, Leen Naji, Mark Phillips, Raman Mundi, and Mohit Bhandari [14] who wrote the publication "Infodemics related to the novel Coronavirus disease, Atefeh Vaezi \& Shaghayegh H. Javanmard [15] the theme of the article, Infodemics and Risk Communication in the Covid-19 Era, Parth Patwa, Shivam Sharma, Srinivas Pykl, Vineeth Guptha, Gitanjali Kumari, Md Shad Akhtar, Asif Ekbal, Amitava Das, and Tanmoy Chakraborty [16] wrote the theme of war with infodemics: Covid-19 fake news data collection, Mark Buchanan [17] with articles on managing infodemics, Azzam Mourad, Ali Sror, Haidar Harmani, Cathia Jenainati \& Mohamad Arafeh [18] wrote articles on the critical impact of social network infodemics in beating the COVID-19 coronavirus pandemic: a direction for Twitter-based research and study, Richard J Medford, Sameh N Saleh, Andrew Sumarsono, Trish M Perl, Christoph U Lehman [19] with an article on an "infodemic": leveraging highvolume Twitter data to understand sentiment public for the 2019 coronavirus outbreak, Alessandro Rovetta \& Akshaya S. Bhagavathula [20] wrote the theme of web search behavior related to COVID-19 Infodemics in Italy: Infodemiological Studies, most recently Xichen Zhang, Ali A. Ghorbani [21] wrote a summary theme fake news online: characterization, detection, and discussion. Before going further, we need to understand what fake news is.

\section{METHOD}

This research uses qualitative approach and emphasizing in literature review method. According to Snyder (2019), a literature review provides the basis for building a new conceptual model or theory, and it can be valuable when aiming to map the development of a particular research field over time [22]. A literature review article provides a comprehensive overview of literature related to a theme/theory/method and synthesizes prior studies to strengthen the foundation of knowledge [23]. 


\section{RESULT AND ANALYSIS}

\subsection{The Nature and Specification ff Fake News}

Before the author go deeper into writing about fake news. Often times, I think about a critical question that is often asked by my colleagues, the question about what is fake news? Bringing up the question of fake news, the author think part of the anxiety of most people is questioning how to think about the real nature of news. News has been defined in a number of ways, from reporting current, interesting, and significant events [24], to stories of events that significantly affect people [25], to dramatic stories about something new or distorted [26]. News is often seen as the output of journalism, a field that is expected to provide "independent, reliable, accurate and comprehensive information" [27]. Because "the primary aim of journalism is to provide citizens with the information they need to be free and self-regulating," journalism is expected to report, above all, the truth. A central element in the professional definition of journalism is adherence to certain standards, such as being objective and accurate. Along with professional responsibilities comes power. Thus, journalists have occupied an influential position in society, namely those who can strengthen and provide legitimacy for what they preach [28]. At the same time, news is socially constructed, and journalists often make subjective judgments about which information to include and which to exclude [29]. Thus, news is vulnerable not only to the preferences of journalists themselves [30], but also to external forces, such as governments, audiences, and advertisers [31]. News is also a unique commodity, in that, while being sold to audiences, it is then sold to advertisers [32], leaving it vulnerable to market forces. Even so, the news is expected to contain accurate and real information. An important survey of American journalists, for example, distinguishes journalists as those involved in the production of reality, not symbolic media content [33]. Journalists "make the news" but that doesn't mean they are fake [34].

So, what makes fake news fake? If news refers to accurate reports of real events [21], what does fake news mean? News should be - and normatively - based on truth, which makes the term "fake news" an oxymoron. The word "fake" is often used interchangeably with words such as copy, forgery, forgery, and inauthentic [35]. The Oxford dictionary defines "fake" as an adjective meaning "not genuine; imitation or fake." A study on detecting fake websites distinguishes two types: "fake sites", which mimic existing websites, and "fake sites", which is a "fraudulent website that tries to appear as a unique and legitimate commercial entity" [36]. A study of fake online reviews also determines the role of intention in determining what is fake. The study defines fake reviews "as fraudulent reviews provided with the intent to mislead consumers in their purchasing decisions, often by reviewers with little or no actual experience with the product or service being reviewed" [37]. Others place fake news in the context of broader misinformation and disinformation [38]. While misinformation refers to "inadvertently sharing false information," disinformation refers to "the deliberate creation and sharing of information known to be false" [39]. The term "fake news" has entered not only scientific discourse but even everyday conversation, being used not only in an attempt to expose false information but also in an attempt to demonize traditional news organizations. Therefore, it is important to understand the concept of fake news. The extraordinary effort will enable systematic study not only of what makes individuals believe in fake news, but how fake news affects public discourse.

From some of the definitions of fake news from the experts above, we can make three components to make the information fake news. TrendLabs Research popularized the concept of the fake news triangle, or three components in order to successfully trick people so that it is difficult to distinguish between real and fake information. This concept is known as the fake news triangle. Similar to the fire triangle, fake news requires all three of these factors to be present to be successful. The absence of any of these three factors will make spreading fake news more difficult, if not impossible [40].

\section{- Media/ Medium}

Fake news is not possible to spread if there is no media as an intermediary. Media has become a medium that connects to a wide audience, and it is now possible to be accessed by other users from various countries, especially after the mass media era to the era of social media technology [41].

\section{- Tools and Services}

Media technology that continues to develop has become an ideal for the dissemination of disinformation campaigns, especially. In recent years, for example, how social networks have often been used to distribute fake news. Since we are familiar with the term promotion to audiences or media users, commercial advertisements in the media have become a spot for the spread of fake news. Some of the arguments for this effort include:

- Costs. For the reach demanded of a fake news campaign, advertising is used as a tool and, of course, is quite costly.

- Anonymity. Often the disseminators of disinformation hide their identities or use fake accounts or bots. 
- Credibility. News sources may prefer stories that allow news to become "viral" so that the reach of its spread can be much wider, let alone using advertisements that can specifically reach age, gender, region, hobbies, and so on.

- Motivation

Fake news is a means to an end, not an end in itself. As if there is a certain actor who assigns promotions on fake news sites for a specific purpose. While posting in any medium can be considered biased to some extent, what sets fake news campaigns apart is that they are often based on nonexistent bogus facts and often use shocking clickbait headlines to attract reading.

The importance of the titles used for headlines cannot be stressed enough. Especially in today's digital era, the attention span of readers is usually very short. Fake news creators will take advantage of fake news content such as using articles that don't make sense, complete with factual and sensational titles to manipulate the public.

After knowing the meaning of fake news according to the experts and understanding the three-component framework to trick people into distinguishing which is fake news and authentic, we will review various historical events how fake news is used by actors or the state for disinformation campaigns. From a historical perspective, we can also see what mediums were used to disseminate tools and services as well as what motivation for fake news to achieve the goal of manipulating the public.

\subsection{Misinformation, Disinformation and Propaganda as a Content of Fake News}

Fabrication information is nothing new. Julie Posetti and Alice Matthews (2018) revealed that the use of disinformation is outdated, but there has never been any technology that has effectively spread it. The development of media technology distinguishes the extent to which fake news affects. This combination of developments presents an unprecedentedly different threat level and implies a wider spread of false and fraudulent information. Thus, the author divides the history of fake news into four parts: Pre-Printing Era, Post-Printing Era, Mass Media Era, Internet Era [42].

\subsubsection{Pre-Printing Era}

The form of writing written on materials such as stone, clay, and papyrus became the medium used by earlier societies. Information in these writings was usually limited to group leaders (emperors, pharaohs, Incas, religious and military leaders, and so on). Controlling information gives some people power over others and may have contributed to the creation of most of the hierarchical cultures we know today. Knowledge was power in those days. Those who control the knowledge, information, and means of disseminating information become group leaders, with privileges that others in the group do not have [43]. In many early state societies, the distinctive remains of leadership artefacts remain such as pyramids, castles, luxurious household items, and more. Misinformation, disinformation and propaganda have long characterized human communication [44].

Some of the information that survives, engraved in stone or baked on tablets or drawn in pictograms, praises the magic and strength of the leaders. Often these messages are reminders to people that the leader is in control of their life. Others were created to ensure that an individual leader would be remembered for his extraordinary prowess, success in battle, or great leadership skills. However, there is no means of verifying the claim whether it is true information or false information.

In the Roman era when Antony met Cleopatra. Octavian launches a disinformation or propaganda campaign against Antony designed to tarnish his reputation. Through a short and sharp slogan written on the coin. These slogans depicted Antony as a woman and a drunkard, implying that she had become a puppet of Cleopatra, who had been ruined by her affair with him. Then Octavian became Augustus or the first Roman Emperor. He takes advantage of fake news to allow him to hack into the system and make him the leader [45].

In the 6th century $\mathrm{AD}$, the Byzantine historian Procopius of Caesarea used fake news to tarnish the reputation of Emperor Justin Ian. Procopius did this in an effort to support Justinian. After Emperor Procopius' death, released a treatise called secret history which discredited the emperor and his wife. The goal was, when the emperor died there was no retaliation, questioning or investigation [46].

\subsubsection{Post-Printing Era}

The invention of the Gutenberg printing press in 1493 led to the simultaneous spread of literacy, allowing for a wider spread of misinformation and disinformation. Those who are literate can easily use these abilities to manipulate information to those who are not. As more people become educated, it becomes increasingly difficult to mislead what is written [47]. As literacy rates increase, printing and selling information eventually becomes economically viable. This makes the ability to write convincingly and authoritatively about a topic a powerful skill.

Leaders always try to have talented writers in their work and to control what information is produced. Printed information is available in a variety of formats and from different sources. Books, newspapers, leaflets, and cartoons are often produced by writers who have a 
monetary incentive. Publishers pay some to provide real news. Others, it seemed, were being paid to write information for the benefit of their employers. In 1522, Italian writer and satirist Pietro Aretino wrote wicked sonnets, pamphlets, and plays. He self-published his correspondence with Italian aristocrats, using their letters to blackmail former friends and customers. If these people fail to provide the money he needs, their distrust will become public. He took the Roman Pasquino style - the nameless witch - to a news satire and parody level [48].

Whereas their writings were satirical (no different from today's Saturday Night Live satire), they planted seeds of doubt in their readers' minds about the powerful people in Italy and helped shape the day's complex political realities. Aretino's Pasquinos was followed by various French fake news stories known as hearsay. The French word hearsay can be used to mean a rumour or an unsubstantiated story. Canard was widespread during the seventeenth century in France. One rumour reported that a monster, which was caught in Chile, was being shipped to France. This report includes carvings of a dragon-like creature. During the French Revolution, Marie Antoinette's face was superimposed on the dragon. The revised image is used to belittle the queen. The queen's surge in unpopularity may have contributed to her abusive treatment during the revolution [49].

Jonathan Swift complained of fake political news in 1710 in his essay "The Art of Political Lying." The spoke of the damage that lies can do, whether ascribed to a specific author or anonymously: The falsehood flies, and the truth limps afterward so that when humans come to be deceived, it's too late; the joke has ended, and the tale has. Take effect. Swift's description of fake news in politics in 1710 closely resembles that of a twenty-first-century writer [50]. In 1835 there was large-scale disinformation - 'The Great Moon Hoax.' The New York Sun published six articles about discovering life on the moon, complete with illustrations of a humanoid bat creature and a bearded blue unicorn. The American writer Edgar Allan Poe wrote in 1844 a hoax newspaper article claiming that a hot air balloon pilot had crossed the Atlantic in a hot air balloon in just three days. His attention to scientific detail and possible plausible ideas led many people to believe the story that journalists failed to find the balloon or balloon maker. The story was recalled four days after publication. Poe is credited for writing at least six stories that turned out to be fake news. The technological revolution has caused the spread of fake news to a wider, wider, and deeper community [51].

\subsubsection{Mass Media Era}

Mass communication developed in the early 20th century marks the process of mass communication to many people. The advent of radio and television caused satirical news making to flourish, sometimes blaming the meaning of being real in news consumers' minds. At this time, they also developed advertising and public relations techniques as marketing capabilities, both by companies and politicians, to persuade the public. At the beginning of this era, there was a lot of misinformation and disinformation in the political sector, both domestically and abroad, as a form of propaganda information.

The first propaganda disinformation carried out by the government was during World War I. The propaganda carried out by the state recruited the armed forces under the pretext of nationalism and patriotism. Various persuasive slogans in the form of propaganda were made, including: "The country needs YOU", "Father, what did you do in the big war?". In 1917 the British then launched a black campaign with disinformation against the German enemy during World War I. The Daily Mail newspaper claimed that Germany was short of food supplies due to the turn of the British Navy, so that German troops used their own corpses to boil them into food, bone meal, and pork food. This had an impact during World War II when early reports of Holocaust atrocities emerged. The disinformation contained in the news in 1917 is said to be due to inaccurate reports of Nazi atrocities and was doubtful when it first appeared. In the same year, Russian Revolution-era Propaganda appeared; Disinformation is one of its strategies aimed at using Russia's rail network to target large masses of people by producing slogans that are striking and colourful. In 1926, Pastor Ronald Arbuthnot Knox fabricated false information to broadcast on BBC radio. The title of the broadcast was "Instantly Broadcast Barricade". During the broadcast, Knox implies that the city of London is under attack by the Communists, Parliament is under siege, and the Savoy Hotel and Big Ben have been blown up. Those who were late listening to the broadcast were spoofs and not actual news broadcasts [52].

The rise of Nazism in 1933, with, Joseph Gobbles specifically established the German Reich ministry of public enlightenment and propaganda. This ministry aims to spread Nazi messages about violence-inciting hatred against Jews, using all media - including theatre and the press. "Nazi propaganda was ... important to motivate them to kill European Jews and other victims. The disinformation also serves to secure the consent of millions of other people and carry out racially targeted persecution and killings". In 1938, the radio drama War of the Worlds in America fooled many listeners without realizing it into believing that the earth was under attack, an alien being. In 1948, the Chicago newspaper 
Daily Tribune wrote about the victory of President Incumbent Dewey. The editor was convinced of the previous presidential election results, so he wrote a headline entitled "Dewey beat True-men" [40].

America carried out attacks against Vietnam from 1955-1975. America continues to carry out propaganda staged at the end of each day at a Saigon hotel dubbed "Five Hour Foolishness". The US Disinformation Campaign is sometimes called the "Optimism Campaign". It was using domino theory as a fear tactic to suppress government opposition to the war. Suppose a country is under Communist influence or control [53]. In Indonesia, in 1965, known as the 30S/PKI Movement, members of the Indonesian armed forces killed six high-ranking Indonesian Army generals. The head of the Army's Strategic Reserves Command, General Suharto, accused the Communist Party of masterminding a coup to take over the country's leadership. After that, Suharto's troops executed at least half a million people for their links to communism. Suharto's military dictatorship, based heavily on anticommunist propaganda and ruled Indonesia with US support until 1988 [54]. In 1983, The Associated Press reporter Fred Bayles interviewed Boston University Professor Joseph Boskin, who researched the day's origins. April mop. Found, it turns out that the history of April Fools' Day comes from the story of a comedian who later became king [55].

It's easy to see that fake news has been around for quite a while. From some of the examples described above, fake news's effects are very diverse, from entertainment to death. Some agents for creating fake news may have various motivations for specific purposes. The impact of fake news, whether intentional or not, from the pre-internet era was very deep and reached widely through the mass media as a means of increasing the spread of fake news, which had increasingly serious consequences.

\subsubsection{Internet Era}

At the end of the 20th century, the internet provided a new way to spread fake news on a much more massive scale. When the internet was created for the public, anyone who had a computer with internet access could access any information in the digital world, true or trashy information. At the same time, technological innovations and lower prices have made access to people wider. Information on the internet is becoming a new way to promote products for everyone. This virtual world then increases the motivation to provide fake news to the public [56]. The internet is now funded by advertisers, whether individual, private, or government, to carry out persuasion and propaganda to convey information to digital citizens.

American government coalition motivated Iraq in 2003 as part of the post 9/11 'Resistance against Terror'; the News York Times published a series of articles including on accounts that were never independently verified informing a camp where 'biological weapons' produced in Iraq.' from 2003 - 2011. The article written by reporter Judith Miller that contains false information about weapons of mass destruction can be said to be among those that have had major consequences for America. This quote was used by the George Bush Jr. administration as one of the reasons for invading Iraq [51]. In 2004, media such as The New York Times issued a statement apologizing for the reporting of weapons of mass destruction. The editorial board admits the story of biological weapons in Iraq is a pattern of misinformation [57].

The Civil War in Syria in 2011, which until now has led to an information war, were launched in conjunction with armed hostilities in Syria. This has led to the spread of false information through social media aimed at discrediting one another. Bashar Assad, for example, accused Amnesty International's 2017 report of false information. Amnesty International launches a 'campaign of extrajudicial executions in Syrian prisons by Assad's middlemen. From 2011 to 2015, as many as 13,000 people who opposed the Assad government were secretly hanged in the report. Also, the use of a chemical attack killed 89 people. However, collaborative forensic reporting The New York Times investigated Assad's claim and concluded that the government had indeed dropped a chlorine bomb on a building in the apartment [58]. In 2013, the Australian media published a fake press release that published an article about ANZ bank withdrawing $\$ 1.2$ billion in funding for Whitehaven Coal's flagship mining project. The press release that appeared to be from ANZ bank was written by anti-coal campaigner Jonathan Moylan and directed the media to an executive. Moylan replaced the executive's phone number with his own. As a result of this news, Whitehaven Coal's shares fell $6 \%$ and lost $\$ 300$ of the company's value [59].

In the United States 2016, in the days before and after the US presidential election, false information circulated during the election describing a child abuse ring that Hillary Clinton allegedly presided. It led to the shooting of a rifle at a restaurant by a believer. Meanwhile, Facebook also claims a massive operation cost $\$ 100,000$ to advertise on Facebook during the two years preceding the election. The New York investigated and conducted research revealing that Russian and Indonesian operators on Facebook used "fake Americans" profiles which were used in the form of bots to post "anti-Clinton" campaign messages [60]. The Brexit issue that developed in the UK took on the same pattern as in America. Ahead of the referendum, Brexit supporters on Instagram were five times more active than usual in campaigning to leave the European Union. This pattern also occurs on Twitter, with various foreign accounts and bots appearing tweeting support 
for the UK to leave the European Union to change public opinion [61].

Pakistan's Defence minister issued a retaliatory warning to Israel for sending counter-weapons in 2016. This was after a fake news website that reported Israel had threatened Pakistan with nuclear weapons. The Pakistani Defence Minister later tweeted," Israel's Defence Minister threatens nuclear retaliation by assuming Pakistan has a role in Syria". Upon identification, the Israeli Defence Minister tweeted, "The report referred to by the Pakistani Defence Minister is completely false," [62]. In 2017, a survey conducted on 2000 samples three months before the presidential election in Kenya in August 2017 found that $90 \%$ of respondents saw fake news, with $87 \%$ of people saying they had seen 'deliberate fake news', this election season, a lot of false information has sprung up in popular social media platforms to persuade voters, thereby causing fear and information bias to influence perceptions and support [63]. The national elections of France and Germany in 2017, in, there were attacks on fake news. British newspaper Independent reported on an Oxford study that found a quarter of political stories shared in France were fake news. This data was obtained based on the collaboration of thirty-seven news organizations and technology partners to crosscheck, verify and refute fake news ahead of the vote. In Germany, it is different from the 2016 US election. The election campaign for the majority of voters is not affected by fake news. The German parliament continues to impose fines of more than $\$ 50$ million on Facebook and other social media companies that do not immediately remove illegal content [64].

All over the world have felt the impact of the Covid19 Pandemic from 2019 to the present. The attack, exacerbated by the increasing infodemic about the coronavirus. The WHO Director, Tedros Adhanom Ghebreyesus, called for resistance to the endemic himself, who revealed that the spread of fake news was as dangerous as the SARS-COV-2 virus. YouTube reports that around $23 \%$ - $26 \%$ of YouTube videos are misleading regarding the spread of false information about COVID-19 [65].

Facebook reported that during March and April 2020, it had put warning labels on around 90 million contents related to COVID-19 misinformation such as fake drugs, anti-vaccine propaganda, and various conspiracy theories related to coronavirus. Because fear, racism, stigma produces unconstructive behaviour and even threatens. At the beginning of the pandemic, there was a phenomenon of panic buying, self-relieving tools, and buying food products at the start of a pandemic. Some other false information resulted in the public perceiving a conspiracy theory and ignoring Health protocol. Even worse, infodemics can also lead to mistakes by the government in taking a strategy to combat the pandemic [61].

Advances in media technology have increased the dissemination of information while democratizing global consumption. There are tangible benefits associated with direct access to information. Information dissemination allows ideas to be shared and links areas previously not covered by mass media access. New media platforms make this possible. However, in a largely ported and advertising-driven media, it profoundly affects the way the media evolves over time. The proliferation of fake news is one of the results. Although the existence of fake news is nothing new, the speed at which it is spread and its global reach are different from that of previous eras. Fake news exists in the same context as real news on the internet. The problem seems to be that it is increasingly difficult to distinguish which news is real and which is fake.

\section{CONCULSION}

Along with the development of technology, the spread of fake news is becoming more massive. The influence of technology or media is enormous on how fake news spreads in society. Technology also affects the cost of spreading false information. In other words, technology becomes a deterministic factor in the dissemination of fake news. In addition, fake news is only being able to spread by elite groups. However, now, everyone can be spreading a piece of fake news. Apart from that, nothing has changed from the function of fake news, namely as a propaganda tool by manipulating information for a particular purpose.

\section{REFERENCES}

[1] V. L. Muzyant and et al, "Fake News on COVID-19 in Indonesia," in Pandemic Communication and Resilience, Springer, Cham, 2021, pp. 363-378.

[2] C. Jackson, "Fake News, Filter Bubbles, and Post-Truth Are Other People's Problems," Global Market Research and Public Opinion Specialist (IPSOS), Washington D.C., 2018.

[3] M. A. Muqsith, "Tantangan Baru Jurnalisme," 'Adalah: Buletin Hukum \& Keadilan, vol. 4, no. 1, pp. 251-258, 2020.

[4] B. Southwell, E. Thorson and L. Sheble, "The Persistence and Peril of Misinformation," in American Scientist, Texas, University of Texas Press., 2018, p. 372.

[5] D. M. J. Lazer, "The Science of Fake News," in Science, 2018, p. 1094-1096.

[6] C. Jack, "Lexicon of lies: Terms for Problematic Information," Data \& Society Logo, 2017. 
[7] E. J. L. Z. L. R. Tandoc, "Defining "Fake," Digital Journalism, vol. 6, no. 2, p. 137-153, 2018.

[8] M. \&. M. V. Muqsith, "Effect Fake News for Democracy," Jurnal Cita Hukum, vol. 7, no. 3, pp. 307-318, 2019.

[9] V. L. Muzykant and M. A. Muqsith, "Social consequences of the 2020 regional elections in Indonesia under the covid-19 pandemic," RUDN Journal of Sociology, vol. 21, no. 3, pp. 536-542, 2021.

[10] J. Zarocostas, "How to fight an infodemic," Elsevier Ltd, 2020.

[11] D. F. N. C. R. V. L. \&. B. T. Orso, "Infodemic and the spread of fake news in the COVID-19era," European journal of emergency medicine: official journal of the European Society for Emergency Medicine, vol. 27, no. 5, p. 327-328, 2020.

[12] R. Nielsen, R. Fletcher, N. B. Newman and P. Howard, "Navigating the 'infodemic': how people in six countries access and rate news and information about coronavirus," Reuters Institute for the Study of Journalism, Oxford, 2020.

[13] D. H. Solomon, R. Bucala, M. J. Kaplan and P. A. \& Nigrovic, "The "Infodemic" of COVID19," Arthritis \& rheumatology (Hoboken, N.J.), vol. 72, no. 11, p. 1806-1808, 2020.

[14] A. E. S. Gazendam, E. Wong, K. Madden, L. Naji, M. Phillips, R. Mundi and M. \& Bhandari, "The "Infodemic" of Journal Publication Associated with the Novel Coronavirus Disease," The Journal of bone and joint surgery, vol. 102, no. 13, p. e64, 2020.

[15] A. Vaezi and S. Javanmard, "Infodemic and risk communication in the era of CoV-19," Adv Biomed Re, vol. 9, no. 10, 2020.

[16] P. Patwa, S. Sharma, S. Pykl, V. Guptha, G. Kumari, M. Akhtar, A. Ekbal, A. Das and T. Chakraborty, "Fighting an Infodemic: COVID19 Fake News Dataset," in Communications in Computer and Information Science, Springer International Publishing, 2021, p. 21-29.

[17] M. Buchanan, "Managing the infodemic," Nature Physics, vol. 16, p. 894, 2020.

[18] A. Mourad, A. Srour, H. Harmanani, C. Jenainati and M. and Arafeh, "Critical Impact of Social Networks Infodemic on Defeating Coronavirus COVID-19 Pandemic: Twitter-Based Study and Research Directions," in IEEE Transactions on Network and Service Management, 2020.

[19] R. J. S. S. N. S. A. P. T. M. \&. L. C. U. Medford, "An "Infodemic": Leveraging high-volume twitter data to understand early public sentiment for the Coronavirus disease 2019 outbreak.,"
Open Forum Infectious Diseases, vol. 7, no. 7, 2020.

[20] A. \&. B. A. S. Rovetta, "Global Infodemiology of COVID-19: Analysis of Google Web Searches and Instagram Hashtags," Journal of medical Internet research, vol. 22, no. 8, p. e20673, 2020.

[21] X. Zhang and A. Ghorbani, "An overview of online fake news: Characterization, detection, and discussion," Information Processing \& Management, vol. 57, no. 2, p. 102025, 2020.

[22] H. Snyder, "Literature Review as a Research Methodology: An Overview and Guidelines," Journal of Business Research, vol. 104, pp. 333 339, 2019.

[23] J. Paul and A. R. Criado, "The Art of Writing Literature Review: What Do We Know and What Do We Need to Know?" International Business Review, vol. 29, no. 4, pp. 1-7, 2020.

[23] J. W. Kershner, The Elements of News Writing, Boston: MA: Pearson Allyn and Bacon, 2005.

[24] B. Richardson, The Process of Writing News: From Information to Story, Boston: MA: Pearson, 2007.

[26] K. H. a. K. C. Jamieson, The Interplay of Influence: News, Advertising,Politics and The Mass Media, Belmont: Wadsworth, 1997.

[27] B. a. T. R. Kovach, The Elements of Journalism: What Newspeople ShouldKnow and The Public Should Expect, New York: Three Rivers Press, 2007.

[28] M. Schudson, The Sociology of News. Edited by Jeffrey Alexander, Contemporary Societies, New York: W.W. Norton \& Company, Inc, 2003.

[29] E. S. a. N. C. Herman, Manufacturing consent: The political economy of the mass media, New York: Knopf Doubleday Publishing Group, 2002.

[30] D. White, "The 'Gatekeeper'. A Case Study in The Selection of News," Journalism Quarterly, vol. 27, p. 383-390, 1950.

[31] P. J. a. R. S. Shoemaker, Mediating the Message in the 21st Century: A Media Sociology Perspective, New York: Routledge, 2013.

[32] J. McManus, "What Kind of Commodity is News.," Communication Research, vol. 19, no. 6, p. 787-805, 1992.

[33] J. Johnstone and E. a. B. W. Slawski, The News People: A Sociological Portrait of American Journalists and Their Work., Chicago: IL: University of Illinois Press, 1976.

[34] M. Schudson, "The Sociology of News Production," Media, Culture \& Society, vol. 11, no. 3, p. 263-282, 1989.

[35] M. Andrea, "Aesthetics of Fake. An Overview," Aisthesis, vol. 9, no. 2, p. 59, 2016.

[36] A. Abbasi, Z. Zhang, D. Zimbra, H. Chen and J. and Nunamaker Jr, "Detecting Fake Websites: 
The Contribution of Statistical Learning Theory," MIS Quarterly, vol. 34, no. 3, p. 435-461, 2010.

[37] D. Zhang, L. Zhou, J. Kehoe and I. and Kilic, "hat Online Reviewer Behaviours Really Matter? Effects of Verbal and Nonverbal Behaviours on Detection of Fake Online Reviews," Journal of Management Information Systems, vol. 33, no. 2, p. 456-481, 2016.

[38] C. Wardle, "medium.com," 1702 2017. [Online]. Available: https://medium.com/1st-draft/fakenews-its-complicated-d0f773766c79. [Accessed 0202 2020].

[39] L. Gu, V. Kropotov and F. and Yarochkin, "The Fake News Machine How Propagandists Abuse the Internet and Manipulate the Public," A TrendLabs Research Paper, 2017.

[40] J. Posetti and A. and Matthews, "A short guide to the history of 'fake news' and disinformation," ICFJ under Creative Commons AttributionShareAlike 4.0 International (CC BY-SA 4.0), 2018.

[41] V. L. Muzykant and et al, "Contemporary Transportation Applications as New Forms of Social Construction Technology," in 2021 Fifth World Conference on Smart Trends in Systems Security and Sustainability (WorldS4), London, 2021.

[42] History of the Ancient World: A Global Perspective, Virginia: The Teaching Company, 2011.

[43] B. Kalsnes, "Fake News," Oxford Research Encyclopedia of Communication, 2021.

[44] R. Atwater, Procopius: Secret History, New York: MI: University of Michigan Press, 1961.

[45] D. Murray, "Changing Technologies, Changing Literacy Communities?" Language Learning \& Technology, vol. 4, no. 2, pp. 39-53, 2000.

[46] J. Burkhardt, "History of Fake News," in Combating Fake News in the Digital Age, ALA TechSource, an imprint of the American Library Association, 2017, pp. 5-9.

[47] R. Darnton, "NYR Daily (blog)," 13022017. [Online]. Available: http://www.nybooks.com/daily/2017/02/13/thetrue-history-of-fake-news/. [Accessed $02 \quad 02$ 2020].

[48] L. Damrosch, Jonathan Swift HIS LIFE AND HIS WORLD, New Haven and London: Yale UNIVERSITY PRESS, 1992.

[49] B. Thornton, "The Moon Hoax: Debates About Ethics in 1835 New York Newspapers," Journal of Mass Media Ethics, vol. 15, no. 2, pp. 89-100, 2000.

[50] E. Moïse, "nytimes," 201711 2017. [Online]. Available:

https://www.nytimes.com/2017/11/20/opinion/jo hnson-propaganda-vietnam-westmoreland.html [Accessed 0203 2020].

[51] V. Bevins, "washingtonpost.com," 30092017. [Online].

Available: https://www.washingtonpost.com/news/worldvie ws/wp/2017/09/30/in-indonesia-the-fake-newsthat-fueled-a-cold-war-massacre-is-still-potentfive-decades-later/?utm_termv. [Accessed 0202 2020].

[52] A. Laskowski, "BU Today," 2009. [Online]. Available:

https://www.bu.edu/articles/2009/how-a-bu-profapril-fooled-the-country. [Accessed 2002 2020].

[53] J. Kenway, "The Information Superhighway and Post-Modernity: The Social Promise and the Social Price," Comparative Education, vol. 32, no. 2, p. 217-231, 1996.

[54] J. Miller, "nytimes," 2104 2003. [Online]. Available:

https://www.nytimes.com/2003/04/21/world/afte reffects-prohibited-weapons-illicit-arms-kept-tilleve-war-iraqi-scientist.html. [Accessed $10 \quad 01$ 2020].

[55] E. De Prang, "The Atlantic," 21032013. [Online]. Available: https://www.theatlantic.com/international/archiv e/2013/03/baghdad-bob-and-his-ridiculous-truepredictions/274241/. [Accessed 1001 2020].

[56] M. Wade, "smh.com.au," 0511 2017. [Online]. Available:

https://www.smh.com.au/national/cyber-armiesinfo-wars-and-fake-news-add-to-syriassuffering-20171105-gzf8a1.html. [Accessed 12 12 2020].

[57] Abc, 1107 2018. [Online]. Available: https://www.abc.net.au/mediawatch/episodes/the -perils-of-speed-before-accuracy/9980876. [Accessed 0111 2020].

[58] S. Shane, "nytimes," 0709 2017. [Online]. Available:

https://www.nytimes.com/2017/09/07/us/politics/ russia-facebook-twitter-

election.html?mtrref=www.google.com.au. [Accessed 1201 2021].

[59] S. Hopkins, "huffingtonpost," 22062016. [Online]. Available: https://www.huffingtonpost.co.uk/entry/nigelfarages-eu-has-failed-us-all-poster-slammed-asdisgusting-by-nicolasturgeon_uk_576288c0e4b08b9e3abdc483. [Accessed 0110 2020].

[60] Irish Times, "irishtimes," 2612 2016. [Online]. Available:

https://www.irishtimes.com/news/world/asiapacific/fake-news-story-prompts-pakistan-to- 
issue-nuclear-threat-1.2917737. [Accessed 1212 2020].

[61] N. Sambuli, "aljazeera.com," 17082017. [Online]. Available: https://www.aljazeera.com/opinions/2017/8/17/h ow-kenya-became-the-latest-victim-of-fakenews/. [Accessed 1701 2021].

[62] S. SHUSTER, "time," 0908 2017. [Online]. Available: https://time.com/4889471/germanyelection-russia-fake-news-angela-merkel/.

[Accessed 0102 2020].

[63] H. Wasserman, 0506 2020. [Online]. Available: $\mathrm{https}$ ://theconversation.com/cultural-factors-arebehind-disinformation-pandemic-why-thismatters-141884. [Accessed 1102 2021].

[64] Z. B. S. A. S. K. N. \&. L. M. Barua, "Effects of misinformation on COVID-19 individual responses and recommendations for resilience of disastrous consequences of misinformation," Progress in Disaster Science, vol. 8, p. 100119, 2020.

[65] M. A. Muqsith and et al, "SOCIAL SOLIDARITY MOVEMENT TO PREVENT THE SPREAD OF COVID-19 PANDEMIC IN INDONESIA," Masyarakat, Kebudayaan dan Politik, vol. 34, no. 2, pp. 147-158, 2021. 